\title{
3. MATERIAIS
}

Este capítulo apresenta e descreve as sementes como materiais foco da pesquisa. Expõe informações sobre sua aquisição, descrição sobre origem, características e propriedades pesquisadas.

\subsection{SEMENTECA}

Há disponível nos diversos biomas brasileiros (floresta amazônica, cerrado, mata atlântica, pantanal, etc.) uma infinidade de sementes que podem ser utilizadas para a produção de produtos artesanais. Dentre todas, uma parte já é conhecida culturalmente para aplicação em adornos (LANA e BENATTI, 2012, p. 243). Como esta pequena fatia das sementes que são encontradas a venda no mercado de peças para a produção de acessórios de moda ainda é um universo muito diverso, até mesmo para se definir uma amostragem para a aplicação de testes foi necessário antes conhecer melhor o objeto de estudo.

Deu-se início então à construção de uma materioteca básica de sementes ornamentais (sementeca) onde foi possível avaliar as características e propriedades das principais sementes encontradas no mercado. Tomou-se como base a "webmaterioteca" do Centro Universitário FEEVALE, que tem em sua estrutura física uma materioteca com foco no design para o setor de calçados, e deixa disponível em seu site as informações sobre as amostras.

\subsubsection{AQUISIÇÃO DE SEMENTES}

O primeiro passo para a construção da sementeca foi a aquisição das sementes. A seleção inicial foi feita a partir da pesquisa de mercado indicando quais as sementes mais recorrentes nos acessórios de moda, assim como sua disponibilidade para compra.

Sementes adquiridas:
1. Açaí
9. Lágrima-de-Nossa-Senhora
17. Tento-carolina
2. Bacaba
10. Morototó
3. Carnaúba
11. Murici
4. Dedo-de-índio
12. Olho-de-boi
5. Feijão-beiçudo
13. Olho-de-cabra
6. Inajá
14. Paxiubão
7. Jarina
15. Paxiubinha
8. Jatobá
16. Jupati 


\subsubsection{INFORMAÇÕES INICIAIS SOBRE AS SEMENTES}

Apresenta a seleção das informações relevantes sobre cada semente e a forma de aquisição.

- Etapa I: descrição

Como o objetivo principal da pesquisa de mestrado é a publicação e divulgação dos resultados, além dos exemplares físicos das sementes fez-se necessário descrever as características para a catalogação dos resultados e tornar possível a consulta por públicos diversos.

As informações apresentadas para cada semente são:

- Nome científico: como forma de certificar exatamente à quais sementes os nomes populares se referem, além de possíveis sinonímias botânicas.

- Nome Popular: nomes comuns pelos quais as sementes são conhecidas no mercado, por produtores e artesãos;

- English common names - nomes comuns em inglês: facilita encontrar informações em fontes internacionais.

- Etapa II: imagens

Além das informações acima, são apresentadas fotografias, a primeira com apenas uma semente e a segunda com um par ou conjunto de sementes.

Esta seção da sementeca consta ainda com mais duas imagens detalhadas produzidas através do MDV-200, equipamento da marca Instrutherm, que consiste em um microscópio varifocal com câmera CCD e LCD. A utilização deste equipamento foi feita em parceria com o CEDTec e o CEMA, centros da Escola de Design da UEMG.

Além das informações sobre a amostra, foi descrito também a ocorrência das sementes no Brasil.

- Etapa III: características

$\mathrm{Na}$ terceira etapa da sementeca, são apresentadas as características de cada semente, desta forma o usuário pode prever e/ou entender melhor as suas propriedades, e assim ter um planejamento mais detalhado em relação ao projeto de biojoia. Estas informações são apresentadas para cada semente e ao final foi feito um estudo comparativo entre elas. As informações são referentes à massa, ao tamanho, ao preço de mercado e a absorção de água, de acordo com o esquema a seguir: 
- Massa: como as sementes são materiais irregulares, para o cálculo da massa foi feita a média entre a medida de 10 sementes, feita através de uma balança com precisão de 0,1g. É importante o cálculo da massa para a produção de acessórios de moda, como forma de garantir o conforto do usuário.

- Tamanho: o tamanho das sementes foi medido através de três dimensões máximas, como mostra a figura 2. A medição foi feita com paquímetro, e devido ao tamanho médio das sementes, o valor está expresso em milímetros. Assim como a massa, para o tamanho foram realizadas 10 medições para cada semente e apresentado a média.

Figura 2 medidas máximas da semente.

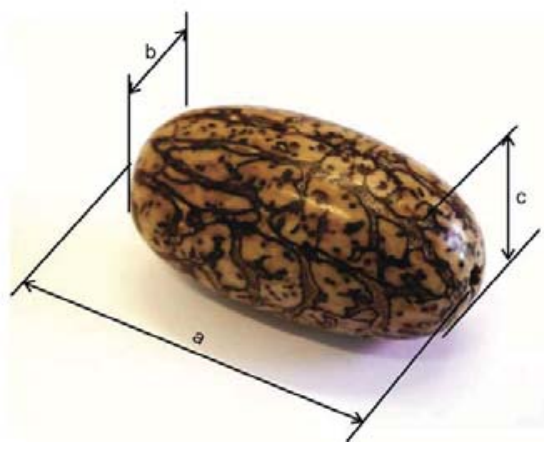

Fonte: a autora (2011).

- Observação: apesar da pesquisa apresentar uma média de massa e tamanho, como um material natural de origem vegetal as sementes podem apresentar grandes variações de acordo com o seu desenvolvimento, idade da planta, quantidade de chuvas, entre outros fatores que podem alterar estas características.

- Absorção: para medir a absorção de água, foi feita a medição da massa das sementes secas, e o nível de absorção foi indicado com pesagens posteriores feitas após deixar a semente ser imersa em água, nos tempos sucessivamente de 2, 4, 8 e 16 horas. Este indicador mostra quais sementes são mais resistentes ao contato com água e quais perdem sua estrutura física e em quanto tempo aproximadamente.

Há ainda espaço para observações relacionadas a qualquer detalhe específico do material, quando relevante para a pesquisa, trazendo os seguintes itens:

- Notas: informações gerais sobre a semente;

- Como é encontrada no mercado: explica em quais as quantidades o consumidor encontrará a semente mais comumente a venda. 


\subsubsection{SEMENTES}

\subsubsection{Açaí}

Figura 3 sementes de açaí.
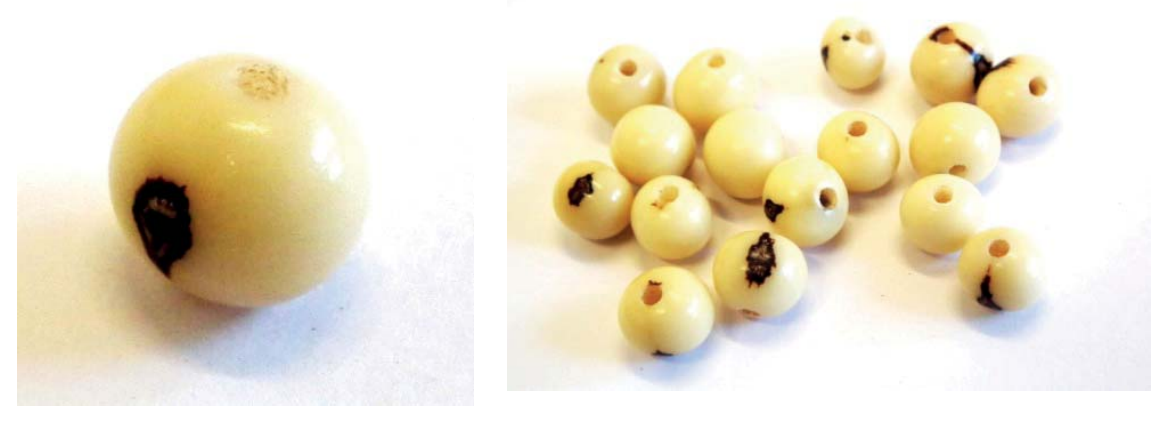

Fonte: a autora (2012).

A maior parte das sementes de açaí utilizadas para o artesanato provém dos frutos utilizados para alimentação. Para análise, considera-se a semente de açaí a Euterpe precatoria (BANDEIRA, 2008, p. 114), porém há outras espécies que podem apresentar uso para o artesanato como a Euterpe oleracea, Euterpe catinga e Euterpe longebracteata.

Figura 4 ampliação da superfície da semente de açaí.
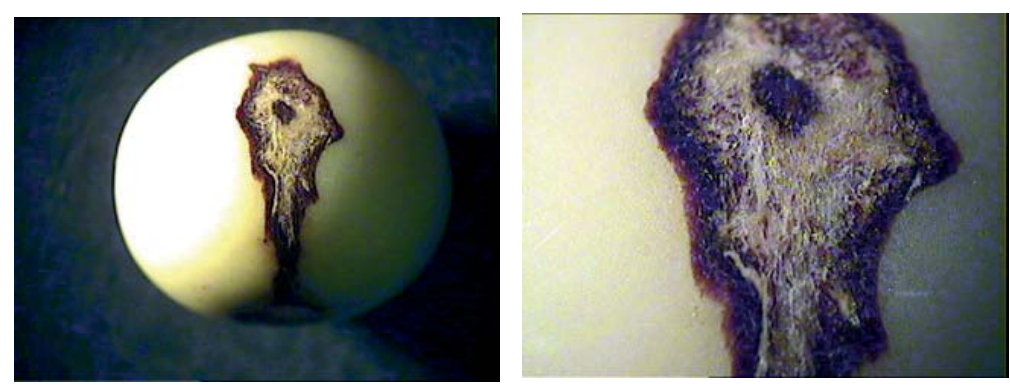

Fonte: a autora (2012).

- Nome científico: Euterpe precatória;

- Nomes populares: açaí-da-mata, açaí, juçara;

- English common names: açaí palm (BANDEIRA, 2008, p. 114); 
- Habitat: ocorre nos estados do Acre, Amazonas, Pará e Rondônia, em matas tropicais úmidas de baixa altitude, geralmente junto aos rios em áreas periodicamente inundadas;

- Utilidade: produz o palmito comestível, são utilizadas pelo potencial paisagístico e do mesocarpo dos frutos é preparado o "vinho de açaî", muito consumido pelas populações locais (LORENZI, et al., 2010, p. 213).

Figura 5 distribuição geográfica do açaí.

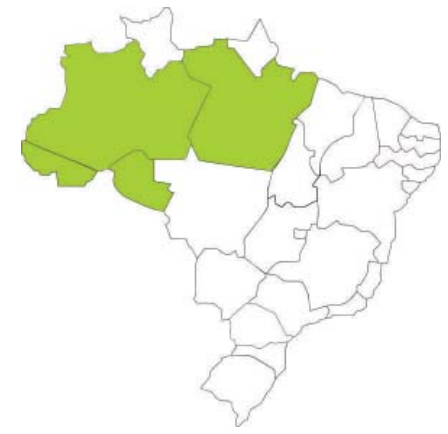

Fonte: a autora (2012) com base em LORENZI et al. (2010, p. 213).

O açaí é uma das sementes brasileiras mais comuns no artesanato, principalmente devido ao amplo uso da palmeira para obtenção do palmito e da polpa do fruto. Pela sua cor clara e maior resistência ao contato com a água, no mercado é encontrada tingida nas mais diversas cores. Pelo tamanho e seu baixo custo é vendida ao artesão em pacotes de 1.000 e 500 unidades.

- Características da semente de açaí:

- Dimensões máximas (média): 8,1×9x8mm;

- Massa (média): 0,3g;

- Preço de mercado: $\mathrm{R} \$ 18,00$ pacote com 1.000 unidades, desta forma $\mathrm{R} \$ 0,018 /$ unidade.

Tabela 12 Teste de absorção do açaí.

\begin{tabular}{|l|l|l|l|l|l|}
\hline Horas & 0 & 2 & 4 & 8 & 16 \\
\hline $\begin{array}{l}\text { Massa } \\
\text { (gramas) }\end{array}$ & 0,4 & 0,5 & 0,4 & 0,6 & 0,5 \\
\hline Observações & - & $\begin{array}{l}\text { Não apresentou } \\
\text { modificação. }\end{array}$ & $\begin{array}{l}\text { Não apresentou } \\
\text { modificação. }\end{array}$ & $\begin{array}{l}\text { Não } \\
\text { apresentou } \\
\text { modificação. }\end{array}$ & $\begin{array}{l}\text { Não } \\
\text { apresentou } \\
\text { modificação }\end{array}$ \\
\hline
\end{tabular}

Fonte: a autora (2013). 
Apesar de ter absorvido $25 \%$ do seu peso, a semente de açaí não apresentou modificações após ficar imersa em água (tabela 12). Apresenta boa resistência mesmo após as 16 horas de imersão, podendo assim ser tingida.

A relação de aumento de massa também deve ser observada com restrições, uma vez que a balança disponível para medição tem precisão de $0,1 \mathrm{~g}$. Para sementes de menor tamanho, como sugestão seria a utilização de maquinário com maior precisão de $0,01 \mathrm{~g}$, ou maior, para instituir os valores mais precisos.

\subsubsection{Bacaba}

Figura 6 Sementes de bacaba.
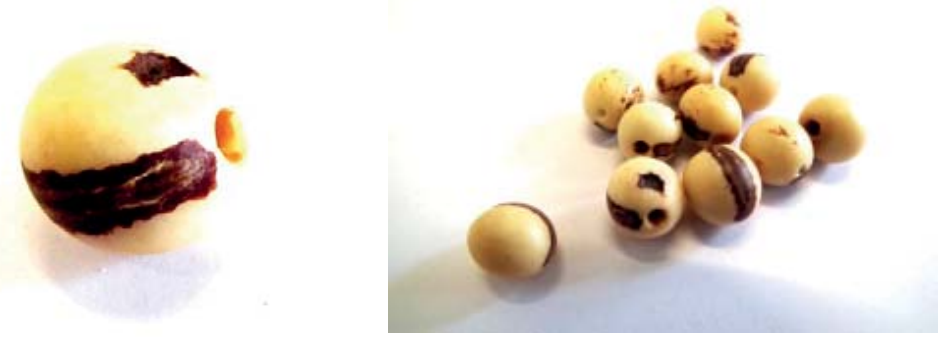

Fonte: a autora (2012).

Semente com coloração e forma muito semelhantes à semente do açaí, sendo o tamanho, um pouco maior, sua principal diferença.

Figura 7 ampliação da superfície da bacaba.
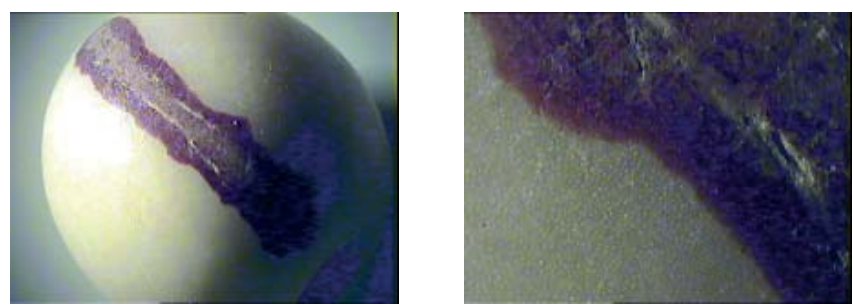

Fonte: a autora (2013).

- Nome científico: Oenocarpus bacaba;

- Nomes populares: bacaba, bacaba-açu, bacabão, bacaba-verdadeira, bacaba-do-azeite, bacaba vermelha;

- English commom names: bacaba palm (BANDEIRA, 2008, p. 115); 
- Habitat: Amazonas e Pará, principalmente ao norte do rio Amazonas, na floresta tropical úmida de terra firme abaixo de $700 \mathrm{~m}$ de altitude. Também na Colômbia, Venezuela e Guianas;

- Utilidade: Os frutos são amplamente empregados nas regiões de origem para o preparo de uma bebida muito apreciada. A planta possui atributos ornamentais que a recomendam para o paisagismo em regiões tropicais (LORENZI, 2010, p. 285).

Figura 8 distribuição geográfica da bacaba.

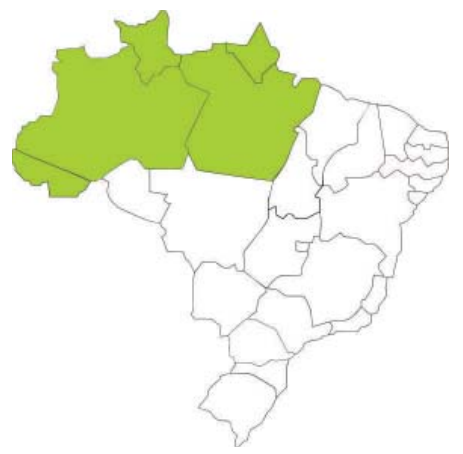

Fonte: a autora (2012) com base em LORENZI et al. (2010, p. 285).

- Características da bacaba:

- Dimensões máximas (média): 11,6x11,2x11,9mm;

- Massa (média): 0,8g;

- Preço de mercado: R\$92,00 pacote com 1.000 unidades, desta forma $\mathrm{R} \$ 0,092 /$ unidade.

Tabela 13 Teste de absorção da bacaba.

\begin{tabular}{|l|l|l|l|l|l|}
\hline Horas & 0 & 2 & 4 & 8 & 16 \\
\hline $\begin{array}{l}\text { Massa } \\
\text { (gramas) }\end{array}$ & 1,0 & 1,2 & 1,2 & 1,3 & 1,3 \\
\hline Observações & - & $\begin{array}{l}\text { Não apresentou } \\
\text { modificação. }\end{array}$ & $\begin{array}{l}\text { Não apresentou } \\
\text { modificação. }\end{array}$ & $\begin{array}{l}\text { Não apresentou } \\
\text { modificação. }\end{array}$ & $\begin{array}{l}\text { Não apresentou } \\
\text { modificação. }\end{array}$ \\
\hline
\end{tabular}

Fonte: a autora (2013).

Como mostra a tabela 13 , a semente de bacaba não apresenta modificações em sua estrutura pelo contato com a água, apesar do aumento da massa de $30 \%$, por isso, assim como o açaí, é encontrada no mercado tingida em diversas cores. Sua venda é feita em embalagens de 10,50,100 e 1.000 unidades. 


\subsubsection{Carnaúba}

Figura 9 sementes de carnaúba.
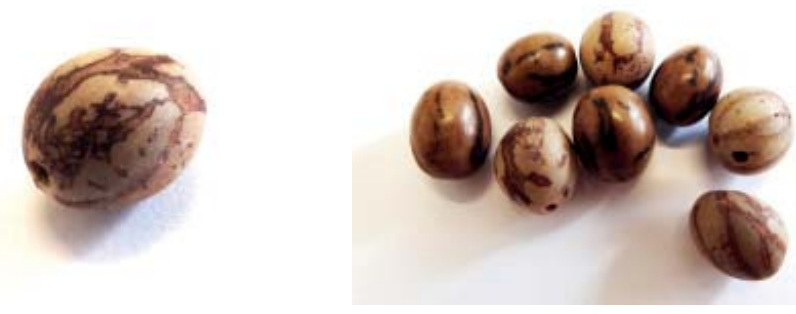

Fonte: a autora (2012).

Semente de cor marrom tem como principal diferencial as estrias escuras que percorrem toda a sua superfície e interior fazendo desenhos diversos.

Figura 10 ampliação da superfície da semente de carnaúba.
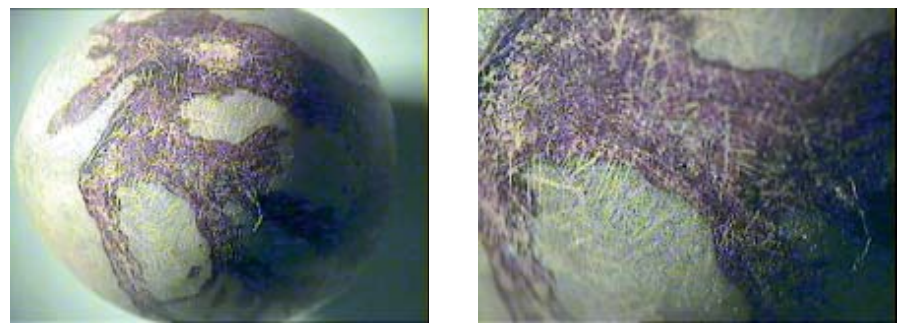

Fonte: a autora (2012).

- Nome científico: Copernicia prunifera;

- Nome popular: carnaúba;

- English common names: carnaúba wax palm (BANDEIRA, 2008, p. 116);

- Habitat: Nordeste brasileiro, na região do Vale do São Francisco, Tocantins e Maranhão, principalmente na vegetação da caatinga, em terrenos baixos de várzea, beira de rios e lagos, bem como em terrenos periodicamente inundados;

- Utilidade: palmeira de grande potencial paisagístico, já é esporadicamente usada na arborização urbana em algumas cidades do nordeste. Sua madeira é forte e se presta para usos diversos. As folhas são empregadas como alimento para o gado e, depois de secas e com a cera retirada, matéria prima nobre para a confecção de artesanato trançado (LORENZI, 2010, p. 196). 
Figura 11 distribuição geográfica da carnaúba.

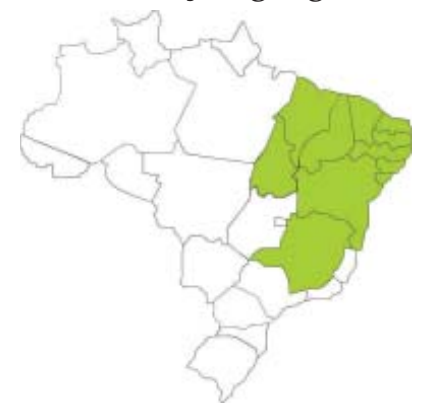

Fonte: a autora (2012) com base em LORENZI et al. (2010, p. 196).

- Características da carnaúba:

- Dimensões máximas (média): 11,4x11,5x13,6mm;

- Massa (média): 1,2g;

- Preço de mercado: $\mathrm{R} \$ 14,00$ o pacote com 100 unidades, sendo R \$0,14/ unidade.

Tabela 14 Teste de absorção da carnaúba.

\begin{tabular}{|l|l|l|l|l|l|}
\hline Horas & 0 & 2 & 4 & 8 & 16 \\
\hline $\begin{array}{l}\text { Massa } \\
\text { (gramas) }\end{array}$ & 1,8 & 1,8 & 1,8 & 1,9 & 2,1 \\
\hline Observações & - & $\begin{array}{l}\text { A água apresentou } \\
\text { tommarrom claro, } \\
\text { porém a semente } \\
\text { ainda manteve sua } \\
\text { estrutura. }\end{array}$ & $\begin{array}{l}\text { Não } \\
\text { apresentou } \\
\text { modificação. }\end{array}$ & $\begin{array}{l}\text { Não } \\
\text { apresentou } \\
\text { modificação. }\end{array}$ & $\begin{array}{l}\text { Apresentou maior } \\
\text { contraste de cor da } \\
\text { semente e suas estrias, } \\
\text { que apresentaram } \\
\text { rachaduras ao final. }\end{array}$ \\
\hline
\end{tabular}

Fonte: a autora (2013).

De acordo com o teste de absorção, a semente é resistente ao contato com a água com aumento de $16,6 \%$ da massa. No entanto em um espaço de tempo menor que as sementes de açaí e de bacaba. No caso da semente de carnaúba, não seria ideal a imersão em água no tempo entre 8 e 16 horas. De qualquer forma o processo de tingimento das sementes leva em média 30 minutos, somado ao tempo de secagem, não é um processo que danifique a semente.

No mercado é encontrada tingida em diversas cores, porém em tons mais fortes, pois sua cor natural é escura, e pode não ressaltar cores claras. É vendida em embalagens de 10, 50, 100, 500 e 1.000 unidades. 


\subsubsection{Dedo-de-índio}

Figura 12 sementes de dedo-de-índio.
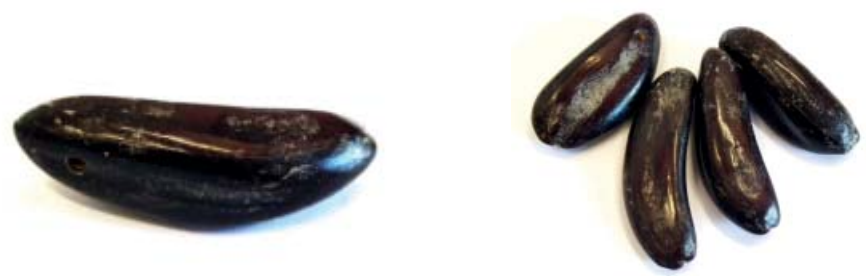

Fonte: a autora (2012).

Semente muito utilizada por seu formato diferenciado, fino e alongado que permite as mais diversas aplicações em biojoias. Apresenta casca escura e com maior durabilidade, enquanto seu interior é claro e macio.

Figura 13 ampliação da superfície da semente de dedo-de-índio.
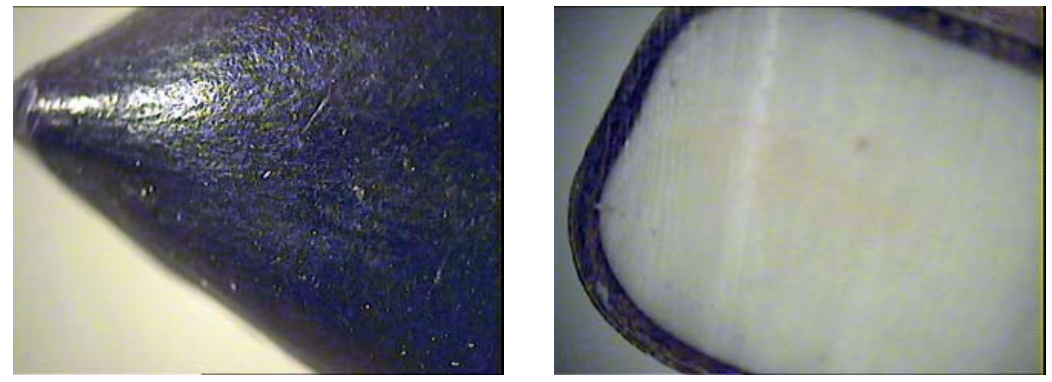

Fonte: a autora (2012).

- Nome científico: Parkia multijuga;

- Nomes populares: dedo-de-índio, tamã, benguê, araraca-tucupi, tucupi, paricá (PA), visgueiro (AM), faveira-benguê, faveira-pé-de-arara;

- English commom names: mimosa (BANDEIRA, 2008, p. 124);

- Habitat: região Amazônica, na floresta de terra firme e várzeas altas em solo argiloso;

- Utilidade: a madeira é empregada apenas como compensados, caixotaria, brinquedos, etc. A árvore é extremamente ornamental;

- Obtenção de sementes: colher os frutos (vagens) diretamente da árvore quando iniciarem a queda espontânea, ou recolhê-los do chão após a queda. 
Em seguida levá-los ao sol para secar e facilitar o quebramento com martelo e retirada das sementes (LORENZI, 2008, p. 204).

Figura 14 distribuição geográfica do dedo-de-índio.

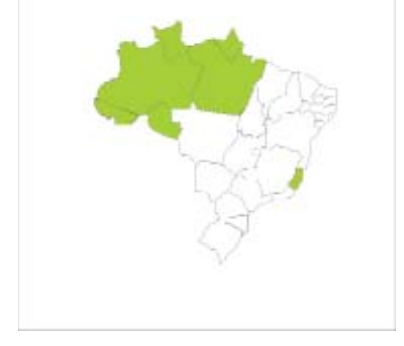

Fonte: a autora (2012).

- Características do dedo-de-índio:

- Dimensões máximas (média): 13,1x16,2x42,8mm;

- Massa (média): 5,9g;

- Preço de mercado: pacote com 50 unidades $\mathrm{R} \$ 45,00$, sendo então $\mathrm{R} \$ 0,90$ a unidade.

Tabela 15 Teste de absorção da semente de dedo-de-índio.

\begin{tabular}{|l|l|l|l|l|l|}
\hline Horas & 0 & 2 & 4 & 8 & 16 \\
\hline $\begin{array}{l}\text { Massa } \\
\text { (gramas) }\end{array}$ & 6,0 & 6,1 & 6,1 & 6,1 & 6,5 \\
\hline Observação & - & $\begin{array}{l}\text { Houve } \\
\text { desprendimento da } \\
\text { película externa da } \\
\text { semente. Imprópria } \\
\text { para uso. }\end{array}$ & $\begin{array}{l}\text { Desprendim } \\
\text { ento da } \\
\text { casca } \\
\text { próximo ao } \\
\text { furo da } \\
\text { semente. }\end{array}$ & $\begin{array}{l}\text { A semente apresenta uma } \\
\text { película escorregadia } \\
\text { externa. Aumento do } \\
\text { desprendimento da casca } \\
\text { ao redor do furo da } \\
\text { semente. }\end{array}$ & $\begin{array}{l}\text { Casca se } \\
\text { desprendeu } \\
\text { da semente. }\end{array}$ \\
\hline
\end{tabular}

Fonte: a autora (2013).

A semente não apresenta boa resistência ao contato com a água. Assim como as sementes de feijão-beiçudo, jatobá, olho-de-boi, olho-de-cabra e tento-carolina, que apresentam uma casca dura, porém o interior de material diferenciado, sendo macio e de coloração clara, absorvem a água rapidamente. No caso do dedo-de-índio, apesar de ter tido o aumento de apenas $8,3 \%$ da massa, a principal reação foi o desprendimento da casca em algumas partes. 
Outro detalhe importante, é que o desprendimento da casca se inicia onde há fissuras, ou seja, o furo para passagem do fio ou qualquer detalhe rachado na casca é a posição inicial do desprendimento quando imersa em água.

\subsubsection{Feijão-beiçudo}

Figura 15 sementes de feijão-beiçudo.
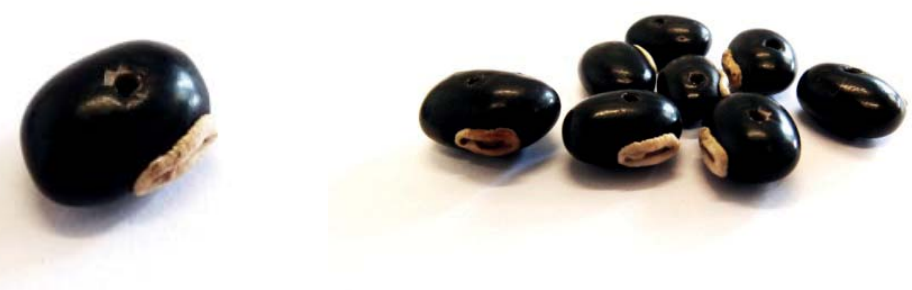

Fonte: a autora (2012).

Muito similar ao feijão comum, utilizado na alimentação, apresenta um detalho claro em sua lateral que se assemelha a um lábio, por isso o nome popular "beiçudo". Assim como o dedo-de-índio apresenta casca mais rígida na cor preta e interior claro e macio.

Figura 16 ampliação da superfície da semente de feijão-beiçudo.
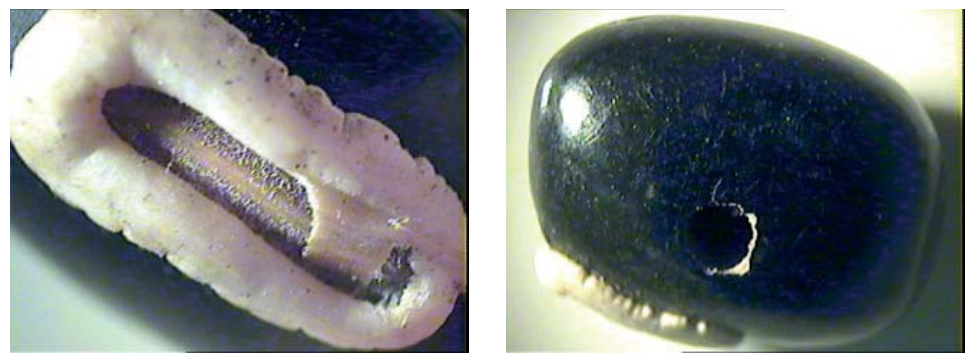

Fonte: a autora (2012).

- Nome científico: Mucuna sp;

- Nomes populares: feijão beiçudo, mucuna preta, pó de mico, fava coceira;

- English common names: black velvetbean (BANDEIRA, 2008, p. 120);

- Habitat: planta nativa do sul da China e leste da Índia, atualmente é amplamente distribuída nos trópicos; 
- Utilidade: adubação verde, cobertura, forragem, alimentação animal e humana e medicinal (FORAGES, 2013).

Figura 17 distribuição geográfica do feijão-beiçudo.

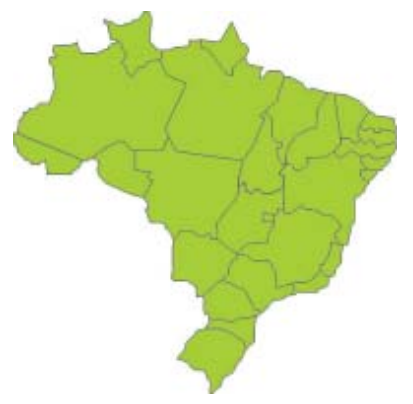

Fonte: a autora (2013) com base em FORAGES (2013).

No Brasil esta planta é muito conhecida como "pó-de-mico", pois as vagens são cobertas por pelos laranja-avermelhados que se soltam facilmente causando irritação intensa na pele (RAINTREE, 2012).

- Características do feijão-beiçudo:

- Dimensões máximas (média): 6,8×9,5×12,7mm;

- Massa (média): 0,6g;

- Preço de mercado: R $\$ 80,00$ o pacote com 1.000 unidades, sendo então $\mathrm{R} \$ 0,08 /$ unidade.

Tabela 16 Teste de absorção da semente de feijão-beiçudo.

\begin{tabular}{|l|l|l|l|l|l|}
\hline Horas & 0 & 2 & 4 & 8 & 16 \\
\hline $\begin{array}{l}\text { Massa } \\
\text { (gramas) }\end{array}$ & 0,8 & 1,4 & 1,4 & 1,4 & 1,4 \\
\hline Observações & - & $\begin{array}{l}\text { A água apresentou } \\
\text { tom marrom claro. } \\
\text { A semente } \\
\text { apresentou inchaço. } \\
\text { Imprópria para o } \\
\text { uso. }\end{array}$ & $\begin{array}{l}\text { A água } \\
\text { apresentou } \\
\text { novamente } \\
\text { coloração marrom } \\
\text { claro. A semente } \\
\text { mais macia. }\end{array}$ & $\begin{array}{l}\text { A água } \\
\text { apresentou } \\
\text { novamente } \\
\text { coloração } \\
\text { marrom claro. }\end{array}$ & $\begin{array}{l}\text { A água } \\
\text { apresentou } \\
\text { novamente } \\
\text { coloração } \\
\text { marrom claro. }\end{array}$ \\
\hline
\end{tabular}

Fonte: a autora (2013).

A semente de feijão-beiçudo se mostrou muito absorvente, tendo sua massa original aumentado $75 \%$ durante o teste, tento deformação da sua forma, apresentando inchaço, e amolecimento. 
O feijão-beiçudo, assim como algumas outras sementes, tem uma capa externa de material diferente e com maior dureza que seu interior. Desta forma observa-se a importância em posicionar corretamente o ferramental para atividades de usinagem, pois a casca da semente se quebra com facilidade, como mostra a figura 18 .

Figura 18 exemplo de quebra da casca da semente provocada pela furação com broca.

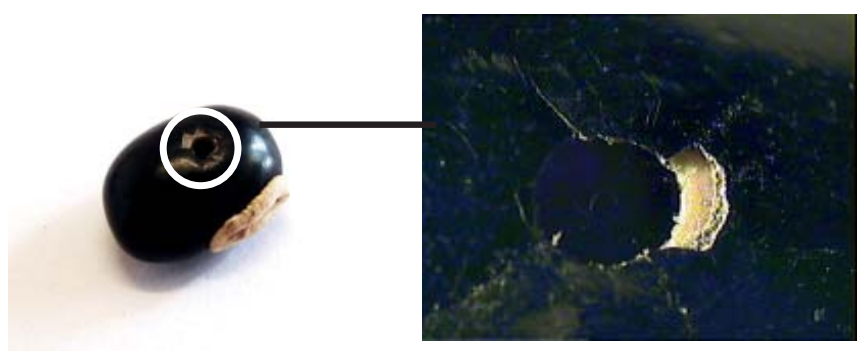

Fonte: a autora (2012).

Por sua coloração escura, e também por não manter sua estrutura física em contato com a água, o feijão-beiçudo não é comercializado com tingimento, ou qualquer outro tipo de acabamento, além do furo padrão para venda. No mercado, é encontrado em embalagens com 10, 50, 100, 500 e 1.000 unidades.

\subsubsection{Inajá}

Figura 19 sementes de inajá.

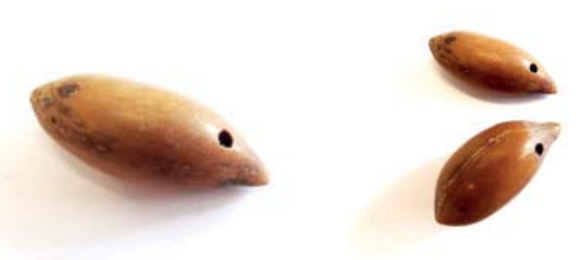

Fonte: a autora (2012).

Semente de coloração marrom clara apresenta forma similar a uma gota, sendo que a furação básica com a qual é vendida no mercado se apresenta sempre posicionada na ponta superior, apresentando-se em forma de pêndulo nas biojoias. 
Figura 20 Ampliação da superfície da semente de inajá.
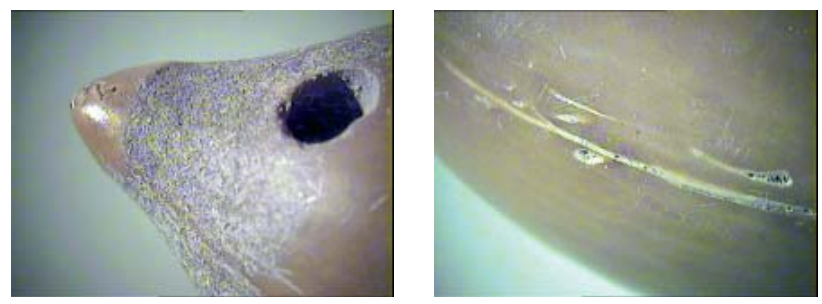

Fonte: a autora (2012).

- Nome científico: Attalea maripa;

- Nomes populares: inajá, inajaí, anajá;

- English common names: inaja palm, American oil palm, cucurite palm, kokerit-palm, maripa palm (BANDEIRA, 2008, p. 118);

- Habitat: Acre, Amazonas, Amapá, Maranhão, Mato Grosso, Roraima, Pará e Rondônia, no interior da floresta de terra firme e em áreas abertas;

- Utilidades: fornece ótimo palmito. A polpa dos frutos é comestível e dela pode ser extraído um óleo amarelo claro comestível. Tem potencial para cultivo com fins ornamentais (LORENZI, 2010, p. 87).

Figura 21 distribuição geográfica do inajá.

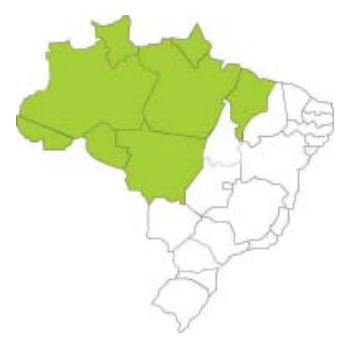

Fonte: a autora (2012) com base em LORENZI et al. (2010, p. 87).

- Características do inajá:

- Dimensões máximas (média): 17,1x15,9x37,1mm;

- Massa (média): 5,1g;

- Preço de mercado: R\$120,00 o pacote com 1.000 unidades, sendo então $\mathrm{R} \$ 0,12 /$ unidade. 
Tabela 17 Teste de absorção do inajá.

\begin{tabular}{|l|l|l|l|l|l|}
\hline Horas & 0 & 2 & 4 & 8 & 16 \\
\hline $\begin{array}{l}\text { Massa } \\
\text { (gramas) }\end{array}$ & 6,6 & 6,8 & 6,9 & 7,0 & 7,0 \\
\hline Observações & - & $\begin{array}{l}\text { Houve leve escurecimento } \\
\text { da casca, porém ainda } \\
\text { manteve a estrutura física. }\end{array}$ & $\begin{array}{l}\text { Não } \\
\text { apresentou } \\
\text { modificação. }\end{array}$ & $\begin{array}{l}\text { Não } \\
\text { apresentou } \\
\text { modificação. }\end{array}$ & $\begin{array}{l}\text { Não } \\
\text { apresentou } \\
\text { modificação. }\end{array}$ \\
\hline
\end{tabular}

Fonte: a autora (2013).

A semente de inajá apresentou comportamento estável durante o teste de absorção de água. A coloração da casca que apresentou escurecimento voltou ao tom normal depois de seca. Sua massa teve o aumento de apenas $6 \%$.

A semente do inajá é formada pelo endocarpo e da amêndoa em seu interior (figura 22). Segundo Araújo, Leitão e Mendonça (2000, p. 34):

O endocarpo apresenta superfície lisa e brilhante, de coloração marrom-clara, raramente com fibras mesocárpicas aderidas; (...); é totalmente aderido ao tegumento, dificultando a separação da amêndoa; de consistência córnea, duro e espesso, com cerca de $5 \mathrm{~mm}$ de espessura (...); pode apresentar septos, ou não, originados de ovário unilocular, bilocular ou trilocular, formando frutos com uma, duas ou três amêndoas, respectivamente (...), sendo que o primeiro e segundo tipos são os mais frequentes (...).

A amêndoa possui forma oblonga, quando única ou apresenta forma e tamanho diferentes, quando em número de duas ou três. O tegumento é, externamente, fortemente aderido ao endocarpo e, internamente, ao endosperma; é fino, apresenta ranhuras marcantes e estreitas que correspondem a ramificações da rafe, conferindo uma textura marmoreada à superfície (...). 
Figura 22 meio corte da semente de inajá com as amêndoas expostas (esquerda) e ampliação (direita).
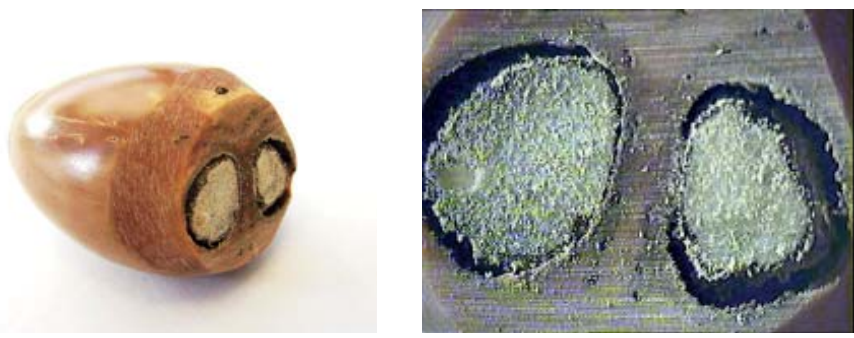

Fonte: a autora (2012).

\subsubsection{Jarina}

Figura 23 sementes de jarina.
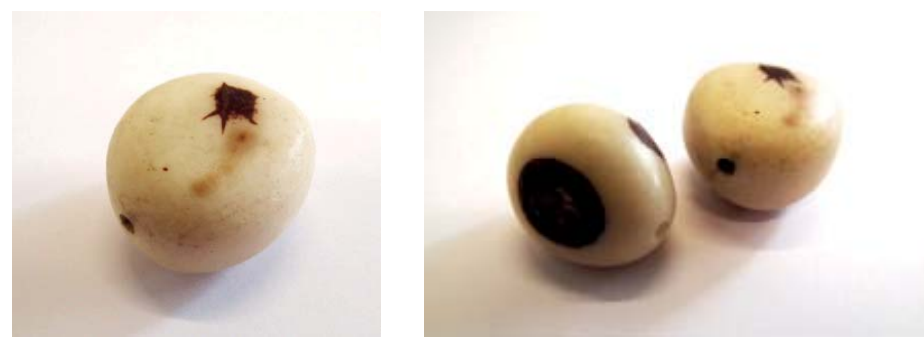

Fonte: a autora (2012).

Uma das sementes mais conhecidas para a produção de biojoias, a jarina apresenta coloração clara muito similar ao marfim animal. Normalmente é comercializada com pontos da casca ainda aderidos a semente. No mercado é encontrada em embalagens de 1.000, 500, 100, 50 e 10 unidades.

Figura 24 ampliação da superfície da semente de jarina.
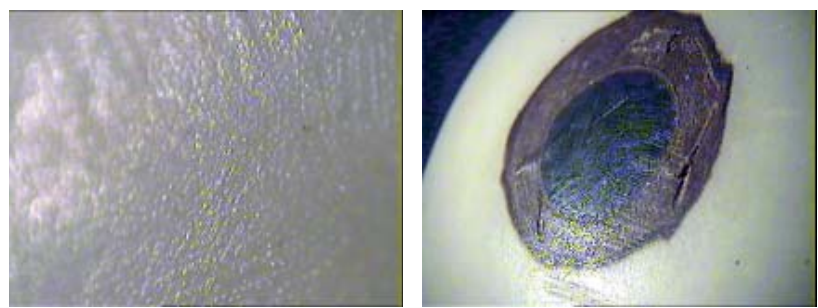

Fonte: a autora (2012). 
- Nome científico: Phytelephas macrocarpa;

- Nomes populares: jarina, marfim vegetal;

- English common names: ivory palm, elephant plant, elephant ivory (BANDEIRA, 2008, p. 118);

- Habitat: Acre e Amazonas, no sub-bosque da floresta úmida densa de terra firme, geralmente em encostas ou nos barrancos inundáveis dos rios. Também na Bolívia e Peru;

- Utilidades: o endosperma endurecido e branco-creme, popularmente denominado de "marfim-vegetal", é esculpido em variados objetos artesanais e outrora industrializado para confecção de botões. As folhas são empregadas na cobertura de casas rústicas (LORENZI, 2010, p. 296).

Figura 25 distribuição geográfica da jarina.

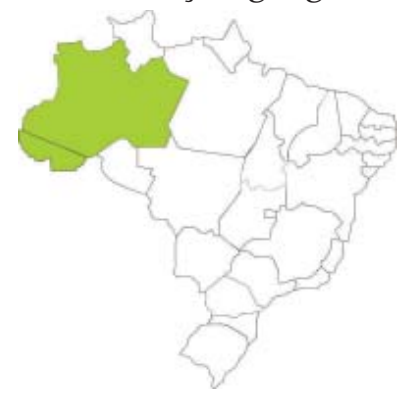

Fonte: a autora (2012) com base em LORENZI et al. (2010, p. 296).

- Características da semente de jarina:

- Dimensões máximas (média): 24,3×21,5×27,1 mm;

- Massa (média): 10,5g;

- Preço de mercado: R \$1.000,00 pacote com 1.000 unidades, sendo então $\mathrm{R} \$ 1,00 /$ unidade.

Tabela 18 Teste de absorção da jarina.

\begin{tabular}{|l|l|l|l|l|l|}
\hline Horas & 0 & 2 & 4 & 8 & 16 \\
\hline $\begin{array}{l}\text { Massa } \\
\text { (gramas) }\end{array}$ & 10,1 & 10,4 & 10,5 & 10,7 & 10,9 \\
\hline Observações & - & $\begin{array}{l}\text { Não apresentou } \\
\text { modificação. }\end{array}$ & $\begin{array}{l}\text { Não apresentou } \\
\text { modificação. }\end{array}$ & $\begin{array}{l}\text { Não apresentou } \\
\text { modificação. }\end{array}$ & $\begin{array}{l}\text { Não apresentou } \\
\text { modificação. }\end{array}$ \\
\hline
\end{tabular}

Fonte: a autora (2013).

Semente apresenta comportamento estável em contato com a água, tendo apenas $7,9 \%$ de aumento de massa ao final das 16 horas do teste. 
Segundo Bandeira (2008, p. 78):

O marfim-vegetal não é uma descoberta recente. Já em 1750, o frei sul-americano Juan de Santa Gertrudis mencionou-o em suas crônicas, comparando as suas sementes a 'bolas de mármore' usadas para entalhar estatuetas. Em 1900, o Equador, principal fonte de marfim vegetal, exportava milhares de sementes, principalmente para a produção de botões. Depois da Segunda Guerra Mundial, o comércio de marfim-vegetal praticamente acabou devido ao surgimento de plásticos, novos e baratos.

\subsubsection{Jatobá}

Figura 26 sementes de jatobá.
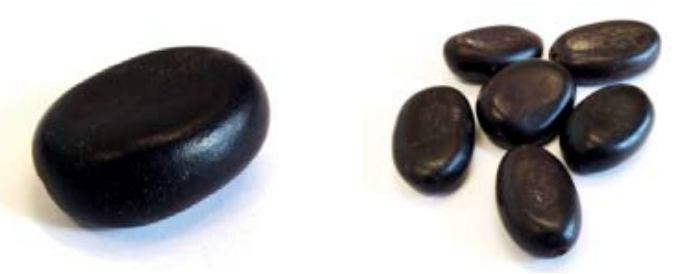

Fonte: LANA e BENATTI (2012).

Para análise, considera-se a semente de jatobá a Hymenaea courbaril (BANDEIRA, 2008, p. 83), porém há outras espécies que podem apresentar uso para o artesanato como a Hymenaea stigonocarpa e Hymenaea martiana.

Semente com casca escura e interior claro e macio. É encontrada no mercado em embalagens com 500, 100, 50 e 10 unidades.

Figura 27 ampliação da superfície da semente de jatobá.
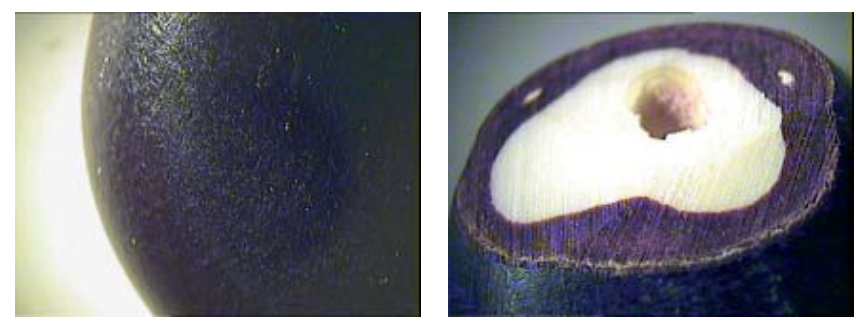

Fonte: a autora (2012). 
- Nome científico: Hymenaea courbail;

- Nomes populares: jatobá, jataí, jataí amarelo, jataí peba, jataí vermelho, jitaí, farinheira, jataíba, burandã, imbiúva, jatobá-miúdo, jatobá-da-caatinga (BA);

- English common names: jatoba, Brazilian cherry, South America Locust, Stinking toe, Brazilian copal, etc (BANDEIRA, 2008, p. 119);

- Habitat: Piauí até o norte do Paraná, na floresta semidecídua, tanto em solos de alta como de média fertilidade (cerradões);

- Utilidade: madeira empregada na construção civil, confecção de artigos de esporte, cabos de ferramentas, peças torneadas, esquadrias e móveis. Árvore utilizada para reflorestamento e o fruto contém uma farinha comestível muito nutritiva;

- Sementes: cada fruta apresenta entre 2 e 4 sementes duras envoltas por uma polpa farinácea;

- Obtenção das sementes: os frutos podem ser colhidos diretamente das árvores quando iniciarem a queda espontânea ou recolhidos no chão logo após a queda. Em seguida devem ser partidos para a retirada manual das sementes e remoção parcial da polpa farinosa que a envolve (LORENZI, 2008, p. 135).

Figura 28 distribuição geográfica do jatobá.

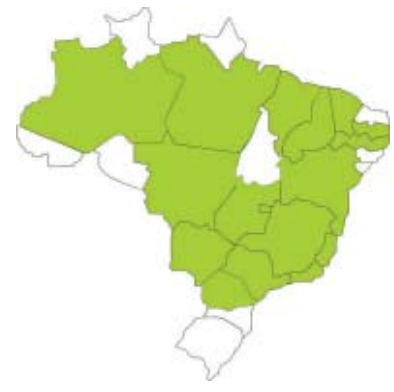

Fonte: a autora (2013) com base em LIMA, 2013.

- Características da semente de jatobá:

- Dimensões máximas (média): 10,9x18,5×29,9mm;

- Massa (média): 4,9g;

- Preço de mercado: $\mathrm{R} \$ 140,00$ o pacote com 1.000 unidades, sendo $\mathrm{R} \$ 0,14 /$ unidade. 
Tabela 19 Teste de absorção do jatobá.

\begin{tabular}{|l|l|l|l|l|l|}
\hline Hora & 0 & 2 & 4 & 8 & 16 \\
\hline $\begin{array}{l}\text { Massa } \\
\text { (gramas) }\end{array}$ & 5,4 & 5,4 & 5,6 & 6,2 & - \\
\hline Observações & - & $\begin{array}{l}\text { A casca ficou quebradiça } \\
\text { e apresentou } \\
\text { deformações similares a } \\
\text { uma bolha com um ponto } \\
\text { de abertura. Imprópria } \\
\text { para o uso. }\end{array}$ & $\begin{array}{l}\text { A casca se } \\
\text { tornou mais } \\
\text { quebradiça } \\
\text { envolta do furo } \\
\text { da semente. }\end{array}$ & $\begin{array}{l}\text { A casca } \\
\text { apresenta } \\
\text { desprendime } \\
\text { nto da } \\
\text { semente. }\end{array}$ & $\begin{array}{l}\text { Não foi } \\
\text { possível fazer a } \\
\text { medição pelo } \\
\text { desprendimento } \\
\text { de parte da } \\
\text { casca. }\end{array}$ \\
\hline
\end{tabular}

Fonte: a autora (2013).

No caso da semente de jatobá houve um aumento de quase $15 \%$ na massa da semente, em 8 horas de imersão em água. Após este tempo não foi mais possível fazer a medição da massa, pois a semente perdeu sua estrutura física, além da deformação e do inchaço, houve ao final o desprendimento da casca.

\subsubsection{Jupati}

Figura 29 sementes de jupati.
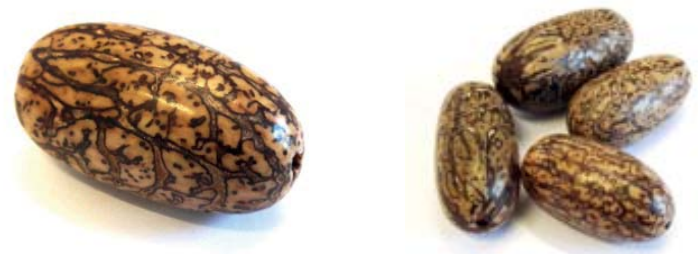

Fonte: a autora (2012).

Semente marrom com diversas estrias escuras em sua superfície que seguem até parte do seu interior. Os desenhos formados pelas estrias no interior das sementes são muito atrativos, fazendo com que esta seja uma das sementes, junto com a jarina, que mais se encontram usinadas no mercado. Para a compra é encontrada mais comumente em embalagens com 50 e 10 sementes. 
Figura 30 ampliação da superfície do jupati.
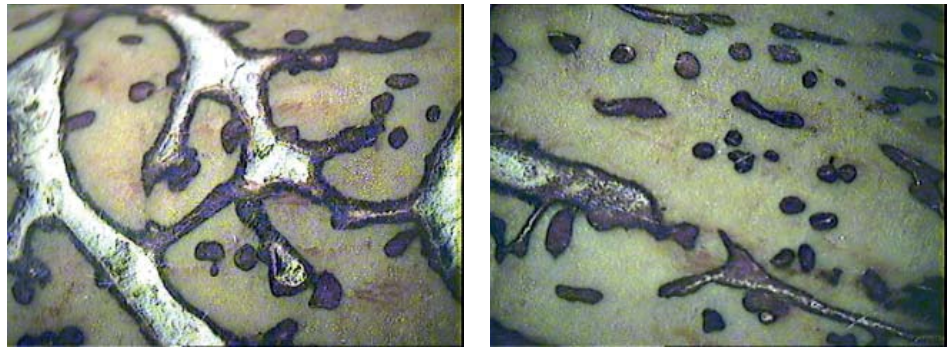

Fonte: a autora (2012).

- Nome científico: Raphia taedigera;

- Nome popular: jupati;

- English common names: raffia palm (BANDEIRA, 2008, p. 119);

- Habitat: ocorre no estado do Pará, no estuário do rio Amazonas, desde a cidade de Belém até Breves, em áreas alagadas litorâneas, próximas de rios sob influência das marés;

- Utilidade: da polpa (mesocarpo) dos frutos é extraído óleo de cor vermelha, utilizado em friç̧ões contra reumatismo e fabricação de sabão. O cacho é utilizado em arranjos ornamentais (LORENZI, 2010, p. 300).

Figura 31 distribuição geográfica do jupati.

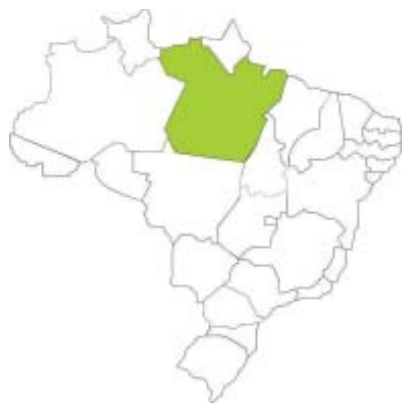

Fonte: a autora (2012) com base em LORENZI et al. (2010, p. 300).

- Características da semente de jupati:

- Dimensões máximas (média): 23,0x23,5x42,7mm;

- Massa (média): 14,9g;

- Preço de mercado: $\mathrm{R} \$ 1.300,00$ a embalagem com 1.000 unidades, sendo $\mathrm{R} \$ 1,30 /$ unidade. 
Tabela 20 Teste de absorção do jupati.

\begin{tabular}{|l|l|l|l|l|l|}
\hline Horas & 0 & 2 & 4 & 8 & 16 \\
\hline $\begin{array}{l}\text { Massa } \\
\text { (gramas) }\end{array}$ & 10,7 & 10,9 & 11,2 & 11,6 & 12,4 \\
\hline Observações & - & $\begin{array}{l}\text { A água apresentou } \\
\text { coloração } \\
\text { levemente marrom. }\end{array}$ & $\begin{array}{l}\text { A água apresentou } \\
\text { coloração levemente } \\
\text { marrom. }\end{array}$ & $\begin{array}{l}\text { Não houve } \\
\text { modificação. }\end{array}$ & $\begin{array}{l}\text { Não houve } \\
\text { modificação. }\end{array}$ \\
\hline
\end{tabular}

Fonte: a autora (2013).

Assim, como o açaí e a bacaba, o jupati é um exemplo das sementes mais resistentes ao contato direto com a água. Apesar de ter havido um aumento de quase $16 \%$ da massa no teste de absorção de água, não houve qualquer modificação aparente na estrutura da semente.

A semente do jupati é uma das mais versáteis no mercado de biojoias, sendo encontrada usinada nos mais diversos formatos. Além da semente polida, ela é uma das poucas que também é comercializada com a casca interna (aderida à semente) e externa, com formato elipsoide, coberta com escamas de cor vermelho-alaranjado.

\subsubsection{Lágrima-de-Nossa-Senhora}

Figura 32 sementes de lágrima-de-Nossa-Senhora.
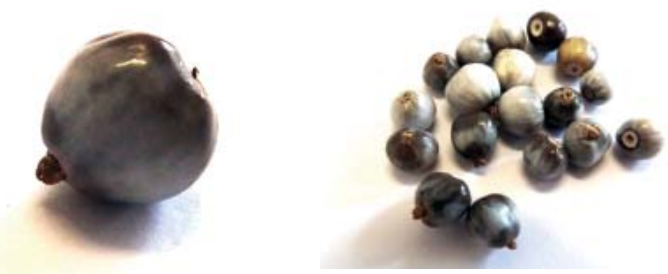

Fonte: a autora (2012).

Semente pequena apresenta coloração clara variando entre tons de cinza e bege. Normalmente não é vendida com a furação básica encontrada nas outras sementes, ficando a cargo do artesão que irá fazer a produção da biojoia. Encontrada no mercado em embalagens com 1.000, 500, 100, 50 e 10 unidades. 
Figura 33 ampliação da superfície da semente.
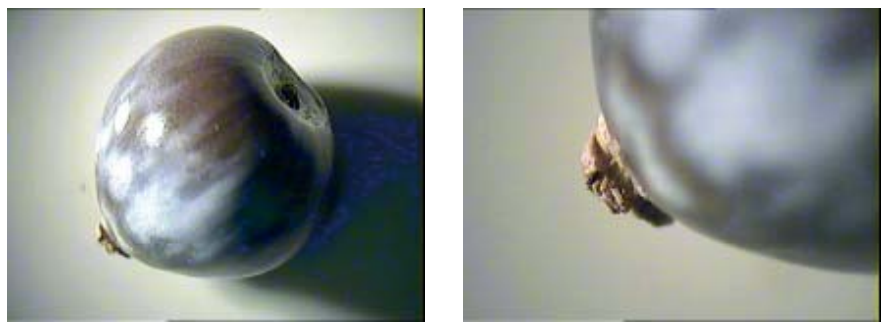

Fonte: própria, 2012.

- Nome científico: Coix lacryma-jobi;

- Nomes populares: Lágrima-de-Nossa-Senhora;

- English common names: job's tears (BANDEIRA, 2008, p. 119);

- Habitat: originária da Ásia tropical naturalizada no Brasil é encontrada no norte (Acre), nordeste (Piauí, Ceará, Paraíba, Pernambuco), centro-oeste (Mato Grosso, Goiás, Distrito Federal, Mato Grosso do Sul), Sudeste (Minas Gerais, São Paulo, Rio de Janeiro) e sul (Paraná, Santa Catarina);

- Utilidade: artesanato, os frutos fornecem uma farinha nutritiva, e as folhas são utilizadas como forragem (FILGUEIRAS, 2013).

Figura 34 distribuição geográfica da lágrima-de-Nossa-Senhora.

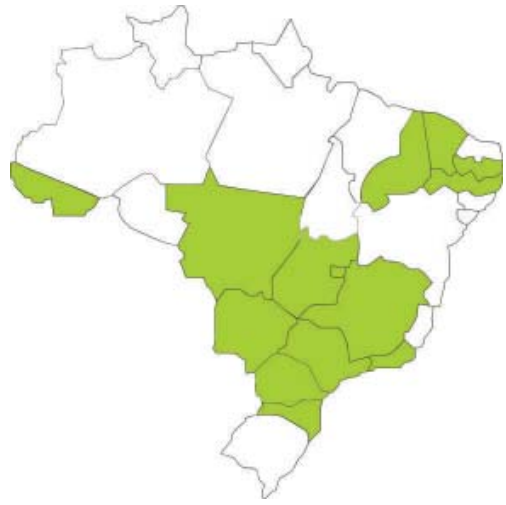

Fonte: a autora (2013) com base em FILGUEIRAS (2013).

- Características da semente de lágrima-de-Nossa-Senhora:

- Dimensões máximas (média): 7,6x6,8x7,2mm;

- Massa (média): 0,2g;

- Preço de mercado: $\mathrm{R} \$ 48,00$ o pacote com 1.000 unidades, sendo $\mathrm{R} \$ 0,048 /$ unidade. 
Tabela 21 Teste de absorção da lágrima-de-Nossa-Senhora.

\begin{tabular}{|l|l|l|l|l|l|}
\hline Horas & 0 & 2 & 4 & 8 & 16 \\
\hline $\begin{array}{l}\text { Massa } \\
\text { (gramas) }\end{array}$ & 0,2 & 0,3 & 0,3 & 0,3 & 0,3 \\
\hline Observações & - & $\begin{array}{l}\text { Apresentou leve } \\
\text { escurecimento da } \\
\text { casca, porém ainda } \\
\text { com estrutura física. }\end{array}$ & $\begin{array}{l}\text { Não } \\
\text { apresentou } \\
\text { modificação. }\end{array}$ & $\begin{array}{l}\text { Apresentoumaior } \\
\text { escurecimento da } \\
\text { semente. }\end{array}$ & $\begin{array}{l}\text { Não } \\
\text { apresentou } \\
\text { modificação. }\end{array}$ \\
\hline
\end{tabular}

Fonte: própria, 2013.

A lágrima-de-Nossa-Senhora é uma semente que apresenta comportamento estável quando imersa em água, havendo pouca mudança de sua estrutura, apesar do aumento de $50 \%$ da massa. Em relação ao escurecimento da semente, assim como a semente de inajá, a casca volta a sua coloração normal após a secagem da semente.

\subsubsection{Morototó}

Figura 35 sementes de morototó.
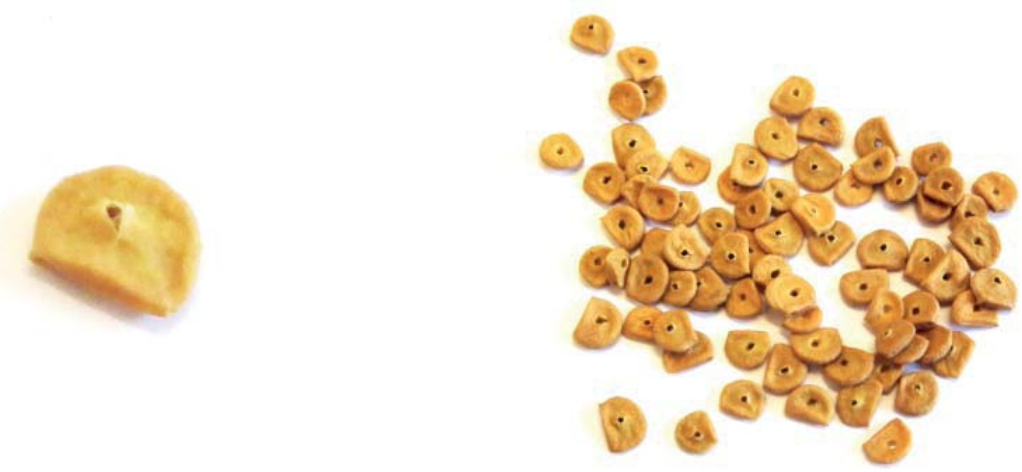

Fonte: a autora (2012).

Uma das menores sementes utilizadas no trabalho com biojoias tem cor bege e formato semicircular. Para fazer sua furação básica, artesãos as furam uma a uma com agulhas de costura fixas em um alicate, utilizando uma borracha como base para que a agulha possa perfurar a semente com mais facilidade. 
Figura 36 ampliação da superfície da semente de morototó.
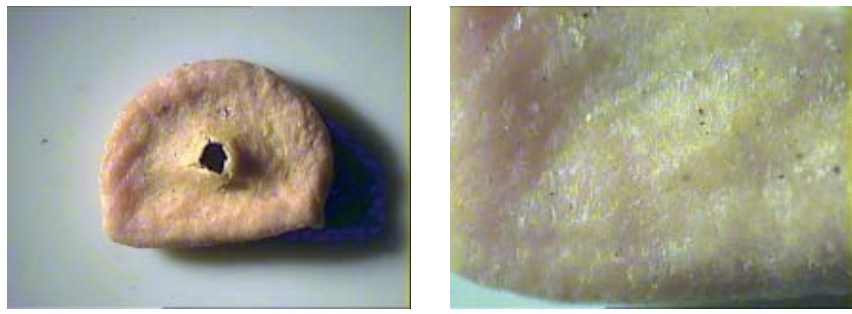

Fonte: a autora (2012).

- Nome científico: Didymopanax morototoni;

- Nomes populares: morototó, mará-mará, mandioqueiro (SP), pau-mandioca, caixeta, marupá, marupaúba, pau-caixeta, para-pará, mucutuba (PA), sambacuim (PE, PB), mandiocaim, mandiocão (SP);

- English common names: match-wood, mountain trumpet (BANDEIRA, 2008, p. 120);

- Habitat: região Amazônica até o Rio Grande do Sul, em várias formações florestais;

- Utilidade: Madeira empregada em contraplacados, compensados, obras de talha, esculturas, molduras, modelos de fundição, marcenaria em geral, portas, batentes, venezianas, brinquedos, lápis, palitos de fósforo, forros, cabo de vassoura, caixotaria, etc. Pode ser empregada no paisagismo pela elegância da árvore;

- Obtenção de sementes: os frutos devem ser adquiridos diretamente da árvore quando adquirirem coloração roxo-escura e iniciarem a queda espontânea (LORENZI, 2008, p. 53).

Figura 37 distribuição geográfica do morototó.

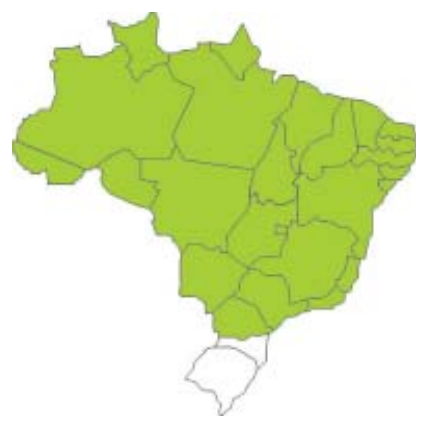

Fonte: a autora (2013) com base em FIASCHI, 2013. 
Suas sementes parecem com um cascalho muito pequeno e tem um tom amarelado (BANDEIRA, 2008, p. 89). Devido ao seu tamanho reduzido e a precisão da balança utilizada $(0,1 \mathrm{~g})$, para fazer o cálculo da massa foi feita a medição de 30 unidades da semente de morototó simultaneamente e o valor foi então dividido.

- Características da semente de morototó:

- Dimensões máximas (média): 3,9x4,8x1,1mm;

- Massa (média): 0,01g;

- Preço de mercado: R\$9,00 o fio com 1 metro de comprimento, que contém aproximadamente 1.000 unidades de semente, sendo assim $\mathrm{R} \$ 0,009 /$ unidade, aproximadamente.

Tabela 22 Teste de absorção do morototó.

\begin{tabular}{|l|l|l|l|l|l|}
\hline Horas & 0 & 2 & 4 & 8 & 16 \\
\hline $\begin{array}{l}\text { Massa } \\
\text { (gramas) }\end{array}$ & 0,013 & 0,016 & 0,016 & $0,016 \mathrm{~g}$ & $0,016 \mathrm{~g}$ \\
\hline Observações & - & $\begin{array}{l}\text { Não houve } \\
\text { modificação. }\end{array}$ & $\begin{array}{l}\text { Não houve } \\
\text { modificação. }\end{array}$ & $\begin{array}{l}\text { Não houve } \\
\text { modificação. }\end{array}$ & $\begin{array}{l}\text { Não houve } \\
\text { modificação. }\end{array}$ \\
\hline
\end{tabular}

Fonte: a autora (2013).

Semente com comportamento estável em contato com a água, teve aumento de $23 \%$ durante o teste de imersão. Devido as suas características estruturais, quando imersas em água (em um primeiro momento) as sementes não afundam por completo no recipiente. A estrutura da semente faz com que ela mantenha ar em seu interior, fazendo-a boiar. No momento do tingimento é importante misturar a água em que a semente está imersa para forçar a entrada de água e assim a semente irá submergir. Caso contrário, pode não haver o tingimento por igual.

\subsubsection{Murici}

Figura 38 sementes de murici.
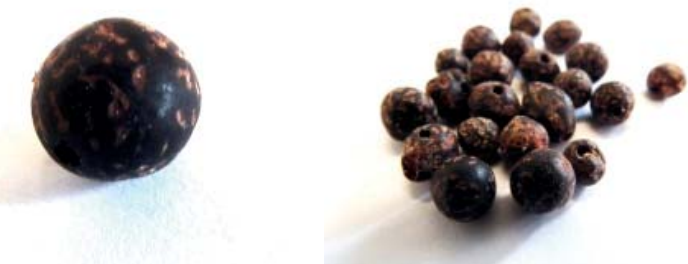

Fonte: a autora (2012). 
Semente pequena, escura, com textura rugosa por toda a superfície. É encontrada no mercado para a venda em embalagens de 1.000, 500,100, 50 e 10 unidades. Existem pelo menos sete espécies de árvores conhecidas como Murici cujas sementes podem ser aproveitadas para o artesanato.

Figura 39 ampliação da superfície da semente de murici.
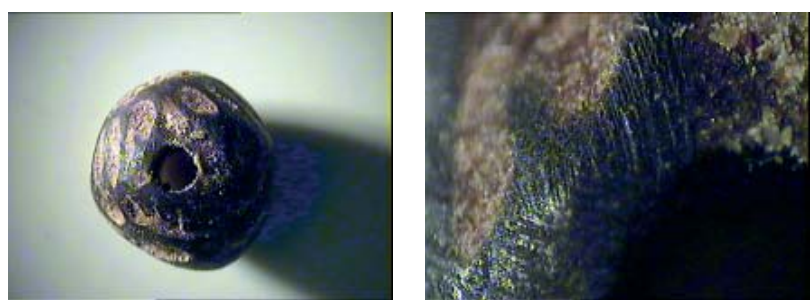

Fonte: a autora (2012).

- Nome científico: Byrsonima coccolobifolia;

Nomes populares: murici-do-cerrado, chaparro-matega, murici-rosa, sumanera (MS), semanera (MS), somanera (MS);

English common names: cork tree (BANDEIRA, 2008, p. 120);

Ocorrência: ampla dispersão nos cerrados e campos cerrados de todo o país (Amazonas ao Paraná e Mato Grosso do Sul), principalmente em terrenos arenosos e bem drenados (LORENZI, 2009, p. 220);

- Nome científico: Byrsonima lancifolia;

Nomes populares: murici-da-capoeira, murici-das-capoeiras, murici-miúdo, murici-rosa, murici-da-serra;

Ocorrência: estados de Minas Gerais e São Paulo, na mata latifoliada semidecídua de altitude. É particularmente frequente na Serra da Mantiqueira em Minas Gerais (LORENZI, 2009, p. 221);

- Nome científico: Byrsonima sericea;

Nomes populares: murici, murici-penima, murici-miúdo, murici-da-praia, murici-da-fruta-miúda, murici-do-brejo;

Ocorrência: São Paulo, Minas Gerais, Goiás e Rio de Janeiro, na mata semidecídua e na restinga litorânea (LORENZI, 2009, p. 222);

- Nome científico: Byrsonima crassifólia;

Nomes populares: murici-do-campo, murici-da-praia, murici, muruci, murici-pitanga, murichi, marajoara;

Ocorrência: regiões Amazônica, Nordeste e Planalto Central, em vegetação campestre, cerrado, duna e savana, sempre em solo arenoso bem drenado (LORENZI, 2009, p. 190); 
- Nome científico: Byrsonima spicata;

Nomes populares: murici-da-capoeira, murici-miúdo, pau-de-curtume;

Ocorrência: região Amazônica, principalmente no estado do Amazonas, na mata pluvial de terra firme (LORENZI, 2009, p. 223);

- Nome científico: Byrsonima stipulacea;

Nomes populares: murici-do-litoral, murici, murici-da-mata;

Ocorrência: sul da Bahia até São Paulo e Minas Gerais, na floresta pluvial atlântica (LORENZI, 2009, p. 224);

- Nome científico: Byrsonima verbascifolia;

Nomes populares: murici-rasteiro (AM), orelha-de-veado, orelha-de-burro (AM), murici, douradinha-falsa, murici-grande, murici-guassu, murici-pequeno (AM), murici-casendo, murici-assu;

Ocorrência: Brasil Central e região Amazônica, em cerrados, cerradões e campos cerrados. É particularmente frequente no Triângulo Mineiro (LORENZI, 2009, p. 225);

Em todos os casos a forma de obtenção das sementes é a mesma:

(...) colher os frutos diretamente da árvore quando iniciarem a queda espontânea ou recolhê-los do chão logo após a queda. Em seguida deixá-los amontoados em saco plástico até a decomposição parcial da polpa visando facilitar a remoção da semente através de lavagem em água corrente dentro de uma peneira (LORENZI, 2009, p. 225).

Figura 40 distribuição geográfica do murici.

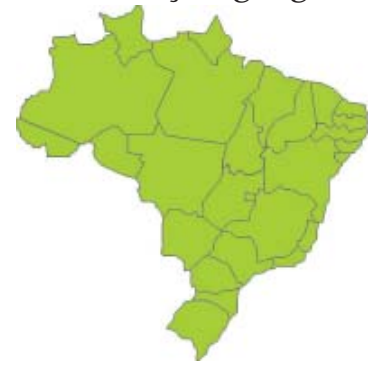

Fonte: a autora (2013) com base em MAMEDE (2013).

- Características da semente de murici:

- Dimensões máximas (média): 7,2x7,2×6,7mm;

- Massa (média): 0,1g;

- Preço de mercado: R\$82,00 o pacote com 1.000 unidades, sendo $\mathrm{R} \$ 0,082 /$ unidade. 
Tabela 23 Teste de absorção do murici.

\begin{tabular}{|l|l|l|l|l|l|}
\hline Hora & 0 & 2 & 4 & 8 & 16 \\
\hline $\begin{array}{l}\text { Massa } \\
\text { (gramas) }\end{array}$ & $0,2 \mathrm{~g}$ & $0,2 \mathrm{~g}$ & 0,2 & 0,2 & 0,2 \\
\hline Observações & - & $\begin{array}{l}\text { Não apresentou } \\
\text { modificação. }\end{array}$ & $\begin{array}{l}\text { Não apresentou } \\
\text { modificação. }\end{array}$ & $\begin{array}{l}\text { Não apresentou } \\
\text { modificação. }\end{array}$ & $\begin{array}{l}\text { Não apresentou } \\
\text { modificação. }\end{array}$ \\
\hline
\end{tabular}

Fonte: a autora (2013).

A semente de murici apresentou bons resultados no teste de imersão em água, não apresentando aumento de massa nem qualquer modificação estrutural.

\subsubsection{Olho-de-boi}

Figura 41 sementes de olho-de-boi.
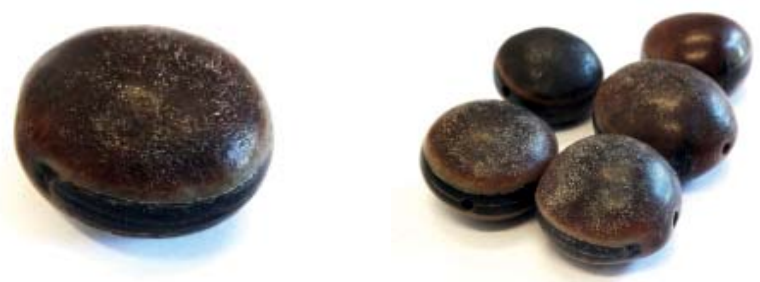

Fonte: a autora (2012).

Sementes de importância mística, sendo muito usadas em oferendas e patuás, contra mau-olhado e para atrair sorte (BANDEIRA, 2008, p. 93). Têm maiores dimensões, apresenta casca em tom de marrom escuro, sendo rígida e quebradiças. Seu interior é claro e macio.

Figura 42 ampliação da superfície da semente de olho-de-boi.
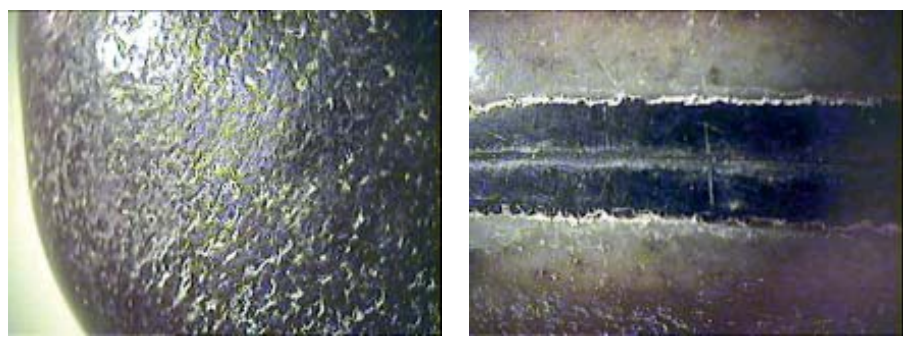

Fonte: a autora (2012). 
- Nome cinetífico: Mucuna urens;

- Nomes populares: olho-de-boi, coronha, olho-de-burro, pó-de-mico;

- English common names: telegraph plant (BANDEIRA, 2008, p. 121);

- Ocorrência: Amazônia e Mata Atlântica, na Floresta Ombrófila Densa e Mista e Restinga;

- Utilidade: revestimentos de grades, cercas externas e caramanchões.

Figura 43 distribuição geográfica do olho-de-boi.

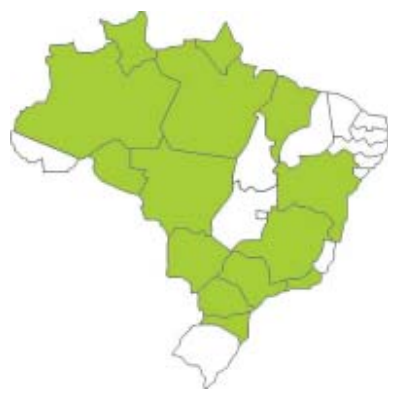

Fonte: a autora (2013) com base em MOURA E TOZZI (2013).

- Características da semente de olho-de-boi:

- Dimensões máximas (média): 19,4x26,8×27,8mm;

- Massa (média): 7,7g;

- Preço de mercado: R\$32,00 a embalagem com 1.000 unidades, desta forma R $\$ 0,32 /$ unidade.

Tabela 24 Teste de absorção do olho-de-boi.

\begin{tabular}{|l|l|l|l|l|l|}
\hline Horas & 0 & 2 & 4 & 8 & 16 \\
\hline $\begin{array}{l}\text { Massa } \\
\text { (gramas) }\end{array}$ & 6,3 & 7,7 & 8,8 & 10,3 & 13 \\
\hline Observações & - & $\begin{array}{l}\text { A água } \\
\text { apresentou tom } \\
\text { marrom claro. A } \\
\text { casca teve } \\
\text { deformações em } \\
\text { forma de bolhas. } \\
\text { Imprópria para } \\
\text { uso. }\end{array}$ & $\begin{array}{l}\text { A água apresentou } \\
\text { novamente } \\
\text { coloração marrom } \\
\text { claro, agora com } \\
\text { partículas em } \\
\text { suspensão. Houve } \\
\text { aumento da } \\
\text { deformação. }\end{array}$ & $\begin{array}{l}\text { A água continuou } \\
\text { apresentando } \\
\text { coloração marrom } \\
\text { claro com partículas } \\
\text { em suspensão. } \\
\text { Houve aumento da } \\
\text { deformação da } \\
\text { semente. }\end{array}$ & $\begin{array}{l}\text { A água } \\
\text { continuou } \\
\text { apresentando } \\
\text { coloração } \\
\text { marrom } \\
\text { aumentou o } \\
\text { inchaço e a } \\
\text { deformação. }\end{array}$ \\
\hline
\end{tabular}

Fonte: a autora, 2013.

A semente de olho-de-boi, como outras leguminosas não apresenta um bom resultado no contato direto com a água. 
A semente amolece, incha, se deforma e tem grande aumento da massa $(106 \%)$. Sendo assim, para este tipo de semente deve haver maior cuidado em relação a umidade, e acima de tudo não deve ser tingida por meio aquoso.

\subsubsection{Olho-de-cabra}

Figura 44 sementes de olho-de-cabra.
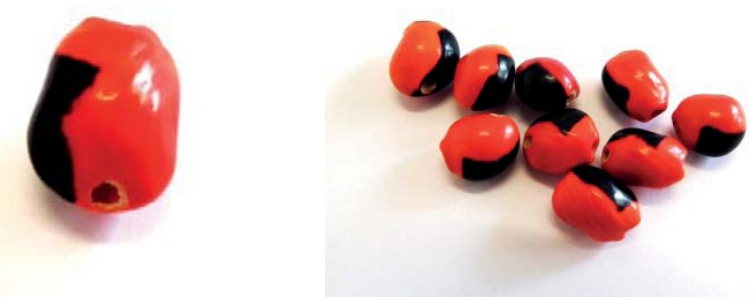

Fonte: a autora (2012).

Semente de cor vermelho vibrante com mancha preta, segundo BANDEIRA (2008, p. 95) "suas sementes imitam um fruto carnoso, o que atrai aves. Quando a ave percebe o engano, já engoliu ou regurgitou a semente, que lançada ao solo, poderá germinar. As sementes também são usadas como proteção contra males”. Vendida no mercado em embalagens de 1.000, 500, 100, 50 e 10 unidades.

Figura 45 ampliação da superfície da semente de olho-de-cabra.
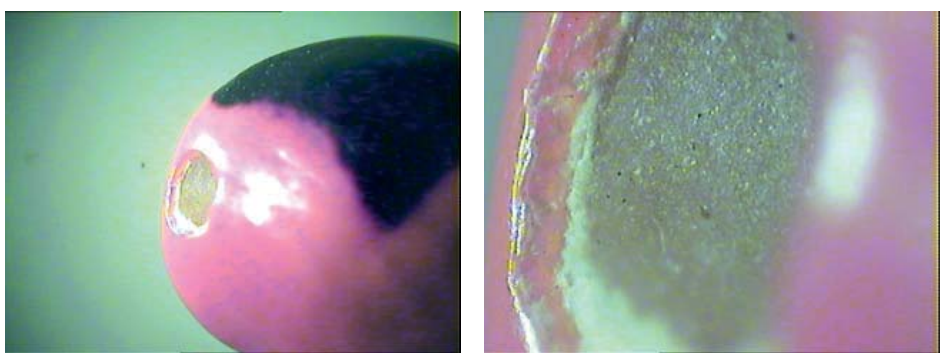

Fonte: a autora (2012).

- Nome científico: Ormosia arbórea;

- Nomes populares: olho-de-cabra, olho-de-boi, pau-ripa (SC), pau-de-santo-inácio (SC), angelim-ripa, coronha;

- English common names: cranefly, venus flytrap (BANDEIRA, 2008, p. 121); 
- Ocorrência: Bahia, Minas Gerais, Mato Grosso do Sul até Santa Catarina, principalmente na floresta pluvial atlântica e latifoliada semidecídua;

- Obtenção de sementes: colher os frutos diretamente da árvore quando iniciarem a abertura espontânea, o que é facilmente notado pela exposição da cor vermelha das sementes. Os frutos assim obtidos devem ser em seguida levados ao sol para que se completem sua abertura e liberação das sementes (LORENZI, 2008, p. 181);

- Utilidade: usada na arborização urbana, sua madeira é empregada na fabricação de móveis e na construção civil (BANDEIRA, 2008, p. 95).

Figura 46 distribuição geográfica do olho-de-cabra.

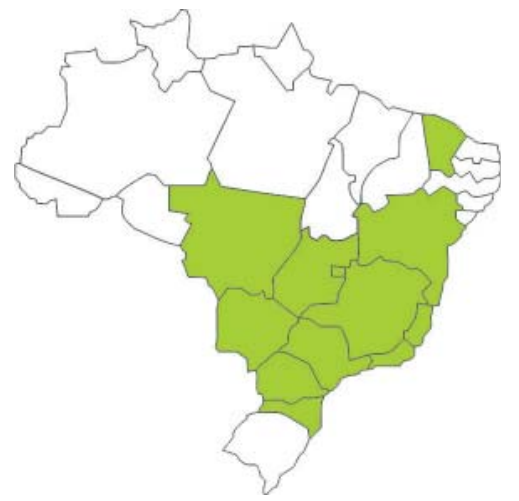

Fonte: a autora (2013) com base em CARVALHO (2013).

- Características da semente de olho-de-cabra:

- Dimensões máximas (média): 8,6x10,3×12,2mm;

- Massa (média): 0,7g;

- Preço de mercado: R\$160,00 o pacote com 1.000 unidades, sendo $\mathrm{R} \$ 0,16 /$ unidade.

Tabela 25 Teste de absorção do olho-de-cabra.

\begin{tabular}{|l|l|l|l|l|l|}
\hline Horas & 0 & 2 & 4 & 8 & 16 \\
\hline $\begin{array}{l}\text { Massa } \\
\text { (gramas) }\end{array}$ & 0,9 & 0,9 & 0,9 & 1,0 & 1,1 \\
\hline Observações & - & $\begin{array}{l}\text { Não apresentou } \\
\text { modificações. }\end{array}$ & $\begin{array}{l}\text { Não apresentou } \\
\text { modificações }\end{array}$ & $\begin{array}{l}\text { Semente apresentou } \\
\text { leve deformidade } \\
\text { nas extremidades. }\end{array}$ & $\begin{array}{l}\text { Manteve a } \\
\text { deformação. }\end{array}$ \\
\hline
\end{tabular}

Fonte: a autora (2013). 
Em comparação com as outras sementes da família das leguminosas (dedo-de-índio, feijão-beiçudo, jatobá, olho-de-boi e tento-carolina), a semente de olho-de-cabra teve melhor comportamento. Não apresentou modificações visíveis até o tempo de 4 horas, porém após este tempo iniciou a deformação similar das outras sementes, acompanhando o aumento da massa $(22,2 \%)$.

\subsubsection{Paxiubão}

Figura 47 sementes de paxiubão.
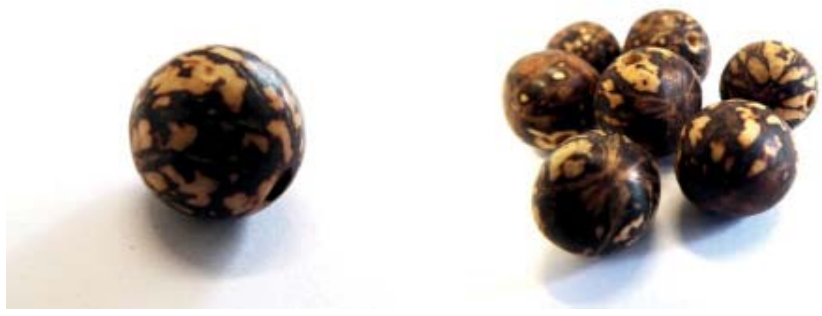

Fonte: a autora (2012).

Semente esférica, de cor bege e casca marrom escuro. Comercializada com e sem a casca aderida. A espécie sempre foi muito usada pelos índios na confecção de vários utensílios, dentre eles a flauta (BANDEIRA, 2008, p. 101). Comercializada tingida nas mais diversas cores, é encontrada em embalagens de 1.000, 500, 100, 50 e 10 unidades.

Figura 48 ampliação da superfície da semente de paxiubão.
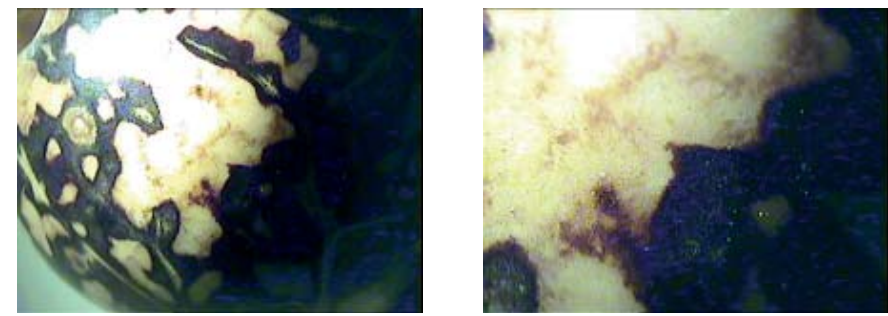

Fonte: a autora (2012).

- Nome científico: Iriartea deltoidea;

- Nomes populares: paxiúba, paxiúba-barriguda, paxiubão, palmeira-barriguda;

- English common names: iriartea, canopy tree (BANDEIRA, 2008, p. 122); 
- Ocorrência: Acre, Rondônia, Amazônas, na floresta tropical úmida de terra firme, geralmente próximo a rios. Também na América Central e na América do Sul tropical;

- A parte externa de seu caule é usada localmente para construções diversas (assoalhos, postes e paredes) e para construção de variados utensílios até canoas. As folhas são empregadas na cobertura de casas e para cestaria (LORENZI et al, 2010, p. 259).

Figura 49 distribuição geográfica do paxiubão.

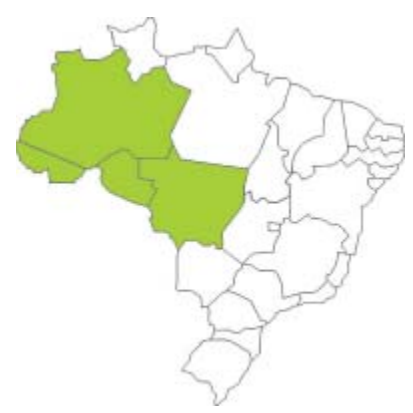

Fonte: a autora (2013) com base em LORENZI et al, 2010, p. 259.

- Características da semente de paxiubão

- Dimensões máximas (média): 14,1x14,2x14,4mm;

- Massa (média): 1,9g;

- Preço de mercado: $\mathrm{R} \$ 150,00$ o pacote com 1.000 unidades, assim $\mathrm{R} \$ 0,15 /$ unidade.

Tabela 26 Teste de absorção do paxiubão.

\begin{tabular}{|l|l|l|l|l|l|}
\hline Horas & 0 & 2 & 4 & 8 & 16 \\
\hline $\begin{array}{l}\text { Massa } \\
\text { (gramas) }\end{array}$ & 2,0 & 2,1 & 2,1 & 2,2 & 2,3 \\
\hline Observações & - & $\begin{array}{l}\text { A água apresentou } \\
\text { coloração marrom claro, } \\
\text { mas não houve perda da } \\
\text { estrutura física. }\end{array}$ & $\begin{array}{l}\text { Não houve modificação } \\
\text { na semente que não } \\
\text { soltou mais coloração na } \\
\text { água. }\end{array}$ & $\begin{array}{l}\text { Não } \\
\text { houve } \\
\text { modifica } \\
\text { ção. }\end{array}$ & $\begin{array}{l}\text { Não } \\
\text { houve } \\
\text { modific } \\
\text { ação. }\end{array}$ \\
\hline
\end{tabular}

Fonte: a autora (2013).

Semente com comportamento estável em imersão em água, com o aumento de $15 \%$ da sua massa original após 16 horas de imersão. 


\subsubsection{Paxiubinha}

Figura 50 sementes de paxiubinha.
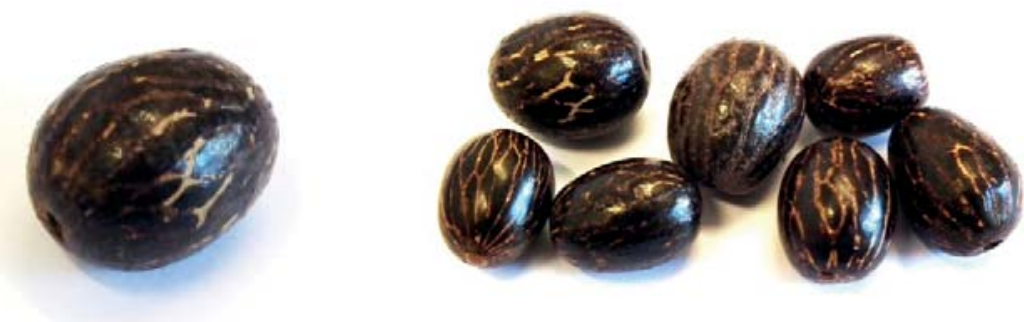

Fonte: a autora (2012).

Semente alongada, com características muito similares ao paxiubão, como a cor da semente e da casca e dureza, também é vendida tingida em diversas cores. É encontrada no mercado em embalagens de 1.000, 500, 100, 50 e 10 unidades.

Figura 51 ampliação da superfície da semente de paxiubinha.
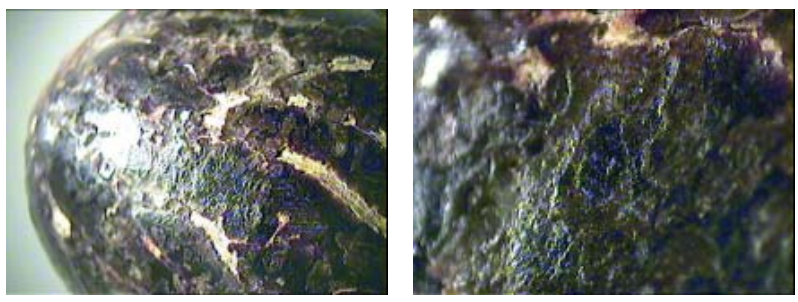

Fonte: a autora (2012).

- Nome científico: Socratea exorrhiza;

- Nomes populares: paxiúba, paxiubinha, castiçal;

- English common names: walking palm (BANDEIRA, 2008, p. 123);

- Ocorrência: Acre, Amapá, Amazonas, Pará e Maranhão, na floresta periodicamente inundada e também em terra firme, sempre próximo de rios e córregos. Também na América Central e norte da América do Sul;

- Utilidade: os caules são rachados e sua parte externa, na forma de pranchas, é largamente utilizada em construções como assoalhos e paredes (LORENZI et al, 2010, p. 302). 
Figura 52 distribuição geográfica da paxiubinha.

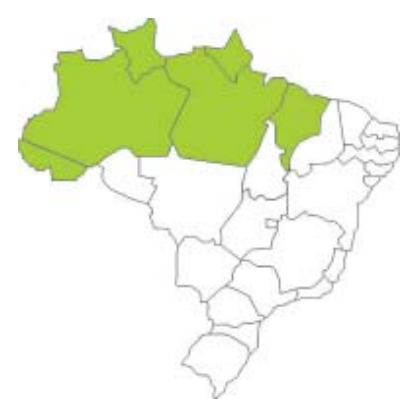

Fonte: a autora (2013) com base em LORENZI et al, 2010, p. 302.

- Características da semente de paxiubinha

- Dimensões máximas (média): 14,1x14,1x21,4mm;

- Massa (média): 2,5g;

- Preço de mercado: R\$140,00 a embalagem com 1.000 sementes, sendo $\mathrm{R} \$ 0,14 /$ unidade.

Tabela 27 Teste de absorção da semente de paxiubinha.

\begin{tabular}{|l|l|l|l|l|l|}
\hline Horas & 0 & 2 & 4 & 8 & 16 \\
\hline $\begin{array}{l}\text { Massa } \\
\text { (gramas) }\end{array}$ & 2,7 & 2,7 & 2,8 & 2,8 & 3,0 \\
\hline Observações & - & $\begin{array}{l}\text { A casca soltou algumas películas, } \\
\text { mas manteve sua estrutura. }\end{array}$ & $\begin{array}{l}\text { Não houve } \\
\text { modificação. }\end{array}$ & $\begin{array}{l}\text { Não houve } \\
\text { modificação. }\end{array}$ & $\begin{array}{l}\text { Não houve } \\
\text { modificação. }\end{array}$ \\
\hline
\end{tabular}

Fonte: própria (2013).

Semente com comportamento similar ao do paxiubão, porém com $11 \%$ de aumento de massa.

\subsubsection{Tento-carolina}

Figura 53 sementes de tento-carolina.
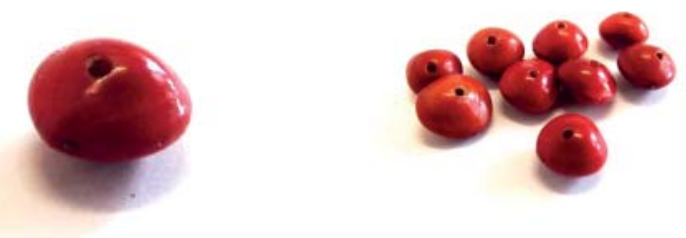

Fonte: a autora (2012). 
Segundo Bandeira (2008, p. 111) o tento é uma planta tipicamente tropical, rústica e de rápido crescimento. Nas feiras, as sementes são vendidas como sendo de pau-brasil, apesar de não haver qualquer semelhança com a planta.

Semente de casca vermelho vivo, rígida e quebradiça. A figura 54 apresenta a quebra da casca devido a furação com broca. Seu interior é macio e de cor clara.

Figura 54 ampliação da superfície da semente de tento-carolina.
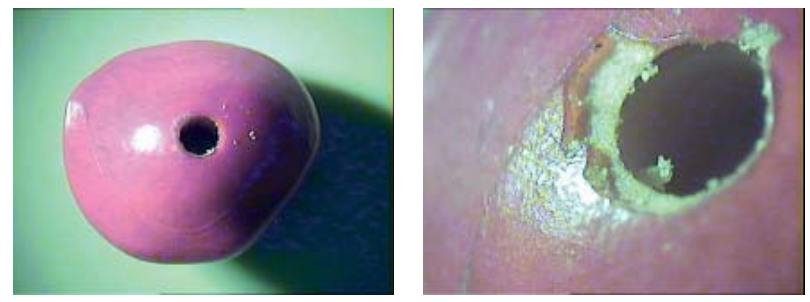

Fonte: a autora (2012).

- Nome científico: Adenanthera pavonina;

- Nomes populares: tento-carolina;

- English common names: red beadtree, Barbados pride, coral-wood, peacock flower fence, red sandalwood tree, red sandalwood, sandalwood tree (BANDEIRA, 2008, p. 124);

- Ocorrência: originária da Índia e da Malásia é encontrada no Brasil em todo o cerrado e no litoral;

- Utilidade: usada em arborização de parques e ruas. Sua madeira é empregada na construção civil e na marcenaria de luxo. As sementes e a madeira são utilizadas como fitoterápicos, no tratamento de infecções pulmonares e da oftalmia crônica (BANDEIRA, 2008, p. 111).

Figura 55 distribuição geográfica do tento-carolina.

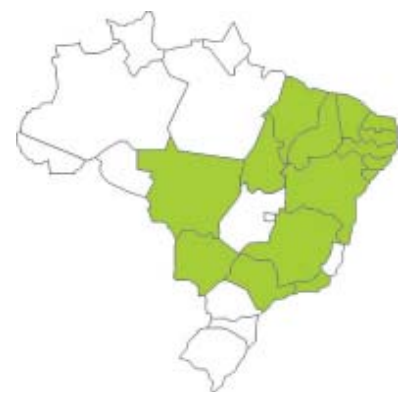

Fonte: a autora (2017) com base em NOSSAS ÁRVORES (2017). 
- Características da semente de tento-carolina:

- Dimensões máximas (média): 8,5x8,9x5,9mm;

- Massa (média): 0,2g;

- Preço de mercado: $\mathrm{R} \$ 48,00$ embalagem com 1.000, sendo $\mathrm{R} \$ 0,048 /$ unidade.

Tabela 28 Teste de absorção do tento-carolina.

\begin{tabular}{|l|l|l|l|l|l|}
\hline Horas & 0 & 2 & 4 & 8 & 16 \\
\hline $\begin{array}{l}\text { Massa } \\
\text { (gramas) }\end{array}$ & 0,3 & 0,3 & 0,3 & $\begin{array}{l}\text { Não foi possível fazer a } \\
\text { conferência da massa } \\
\text { devido à deterioração } \\
\text { física da semente. }\end{array}$ & - \\
\hline Observações & - & $\begin{array}{l}\text { A água apresentou } \\
\text { tom alaranjado. } \\
\text { Leve deformação da } \\
\text { casca próxima ao } \\
\text { furo. Imprópria para } \\
\text { o uso. }\end{array}$ & $\begin{array}{l}\text { A água novamente } \\
\text { com tom alaranjado. } \\
\text { Houve aumento da } \\
\text { deformação e perda } \\
\text { da coloracão } \\
\text { próximoao furo. }\end{array}$ & $\begin{array}{l}\text { A água apresentou } \\
\text { novamente tom alaranjado. } \\
\text { Houve aumento da } \\
\text { deformação, perda da } \\
\text { coloraccão próximo ao furo } \\
\text { edesprendimento da casca. }\end{array}$ & - \\
\hline
\end{tabular}

Fonte: a autora (2013).

A semente não apresentou aumento da massa até o tempo de 4 horas, porém foi deformando sua estrutura aos poucos, não sendo possível fazer a medições posteriores. 
